\title{
Study of Soil Factors Affecting Development of Collar Rot Disease in Chickpea
}

\author{
S.S. Shirsole*, N. Khare, N. Lakpale and A.S. Kotasthane \\ Department of Plant Pathology, IGKV, Raipur, Chhattisgarh, India \\ *Corresponding author
}

\begin{tabular}{|l|}
\hline Ke y w o r d s \\
Vertisol, Chickpea, \\
collar rot, \\
Sclerotium rolfsii, \\
Soybean, Drybean, \\
Turn yellow \\
\hline Article Info \\
\hline $\begin{array}{l}\text { Accepted: } \\
\text { 22 October } 2019 \\
\text { Available Online: } \\
\text { 10 November } 2019\end{array}$ \\
\hline
\end{tabular}

A B S T R A C T
The present study elucidated the role of different soil parameters viz., soil type, texture and $\mathrm{pH}$ on population dynamics of $S$. rolfsii in the development of collar rot of chickpea. In case of soil types [alfisol (dorsa), inceptisol (matasi), vertisol (kanhar) and entisol (bhata)] least mortality per cent $(15.27 \%)$ was observed in inceptisol (matasi) soil whereas highest mortality was observed in vertisol (kanhar) (56.02\%). The infected soil of different textures (sandy, sandy loam, loam, clay, clay loam, silt clay and silt loam), showed least mortality per cent $(20.74 \%)$ in sandy loam texture followed by sandy texture $(26.67 \%)$. However, highest mortality was observed in clay texture soil $(63.22 \%)$, followed by clay loam $(45.83 \%)$. In case of different soil $\mathrm{pH}(5.0,5.5,6.0,6.5,7.0,7.5,8.0$ and 8.5) significantly least mortality per cent $(19.90 \%)$ was observed at $\mathrm{pH} 8.5$ followed by $\mathrm{pH} 8(24.07 \%)$ and $\mathrm{pH} 7.5$ (38.42\%) However, highest mortality was observed at $\mathrm{pH} 6.0$ it was $80.75 \%$.

\section{Introduction}

Chickpea (Cicer arietinum L.) is the world's third most important food legume after drybean and pea. India is the largest producer of chickpea, contributing more than 70 per cent of the total world production. Among the soil borne diseases of chickpea, collar rot is important disease causing seed rot and seeding mortality in the initial stage of crop growth up to 45 days. The mortality ranges from 54.7-
95\% in India (Kotasthane et al., 1976) causing significant reduction in plant population. Collar rot caused by Sclerotium rolfsii Sacc., is one of the several fungal diseases affecting this crop and is reported almost all over the world where ever chickpea is grown (Nene et al., 1984). Collar rot is a fast spreading and destructive disease of chickpea. It has wide host range (Aycock, 1966 and Punja, 1988) and an omnivorous soil borne fungus, parasitizing root and collar region of the plant 
thus, producing wilt like symptoms. Generally, the disease is severe in loamy soil regions and more prevalent in soybean- paddy based cropping system, when soil moisture is high and temperature is warm at the seedling stage. Affected seedlings turn yellow and die. The seedlings generally collapse and show rotting at the collar region and below. Root disease severity is strongly influenced by soil type, soil $\mathrm{pH}$, soil temperature, moisture, and the biological activity of suppressive microorganism. The present study was conducted to ascertain the role of different soil parameters viz., soil type, texture and $\mathrm{pH}$ on population dynamics of $S$. rolfsii in the development of collar rot of chickpea.

\section{Materials and Methods}

\section{Isolation of pathogen Sclerotium rolfsii from diseased samples}

Isolation was made from the fresh diseased plant samples collected from research farm at seedling and vegetative stage of the crop. The roots of diseased plant showing symptoms were washed thoroughly with water, small pieces of infected roots were cut with the help of sterilized blade. These pieces were surface sterilized with 1:1000 mercuric chloride $\left(\mathrm{HgCl}_{2}\right)$ solution for one minute followed by three washings with sterilized distilled water to remove traces of $\mathrm{HgCl}_{2}$. The pieces were then transferred aseptically to Petri plates containing sterilized PDA and incubated at $25 \pm 2^{0} \mathrm{C}$ for three to five days and examined at frequent intervals to see the growth of the fungus developing from different pieces. As and when fungal colony appears they were transferred to PDA slant for purification of culture.

\section{Mass multiplication of Sclerotium rolfsii}

The $S$. rolfsii was mass multiplied in wheat grain media. Wheat grains were soaked in water for $6 \mathrm{hrs}$ then little boiled, drained excess water, air dried and supplemented with $50 \mathrm{~g}$ calcium carbonate in $1 \mathrm{~kg}$ wheat grains. Two hundred gram wheat grains were filled in $6 \times 11$ inches polythene bags and plugged with non absorbent cotton with the support of one inch diameter PVC ring (length 1.5 inch). These bags were sterilized in autoclave with $1.02 \mathrm{~kg} / \mathrm{cm}^{2}$ pressure for $25-30$ minutes. The sterilized bags were inoculated with 2-3 mycelial discs $(5 \mathrm{~mm})$ taken from the periphery of the with 5 days old culture of $S$. rolfsii previously grown on PDA. The inoculated bags were incubated in BOD incubator at $25 \pm 2{ }^{0} \mathrm{C}$ for 15 days. Multiplied culture of $S$. rolfsii utilized for development of artificially sick pot of $S$. rolfsii use in different trials.

\section{Effect of soil type}

The four soil types viz., (Alfisol (Dorsa), Inceptisol (Matasi), Vertisol (Kanhar) and Entisol (Bhata)) were obtained from adjointing fields of College of Agriculture, Raipur. The inoculum of $S$. rolfsii was allowed to multiply on wheat grain media. The inoculum of $S$. rolfsii was added @ $25 \mathrm{~g} / \mathrm{kg}$ in each soil texture mixed thoroughly and left for 5 days, for establishment of inoculum. Five surface sterilized seeds of chickpea were sown in each pot and data on per cent mortality were recorded 15 days after sowing. Treatment details are given in Table 1.

\section{Soil texture}

Soil sample was taken in a beaker and $15 \mathrm{ml}$ sodium hexametaphosphate $(10 \%)$ was added and stirred for 10 minutes in a $1000 \mathrm{ml}$ beaker. The contents were transferred to $1000 \mathrm{ml}$ measuring cylinder with volume make up. At 5 minutes and 5 hours, temperature and hydrometer reading were taken. Percentage of sand, silt and clay were determined with the help of Bouyoucos hydrometer (Piper, 1950) 
and the textural classes were determined with the help of textural diagram (International system). In the present study seven textures were under taken viz., sandy, sandy loam, loam, clay, clay loam, silt clay and silt loam.

The inoculum of $S$. rolfsii was allowed to multiply on wheat grain media. The inoculum of $S$. rolfsii was added @ $25 \mathrm{~g} / \mathrm{kg}$ in each soil texture mixed thoroughly and left for 5 days, for establishment of inoculum. Five surface sterilized seeds of chickpea were sown in each pot and data on per cent mortality were recorded 15 days after sowing.

\section{Effect of soil pH}

In order to determine the effect of different soil $\mathrm{pH}$ on development of disease, soil was collected from experimental field of Department of Plant Pathology. Twenty gram of soil was taken and suspended in $40 \mathrm{ml}$ sterile distilled water in $250 \mathrm{ml}$ conical flask and stirred for $30 \mathrm{~min}$. The soil $\mathrm{pH}$ was estimated 6.5. The soil $\mathrm{pH}$ was adjusted to 5.0, 5.5, 6.0, 6.5, 7.0, 7.5, 8.0 and 8.5 by using $\mathrm{NaOH}$ and HCL (Kulkarni, 2007). The inoculum of $S$. rolfsii was allowed to multiply on wheat grain media. The inoculum of $S$. rolfsii was added @ $25 \mathrm{~g} / \mathrm{kg}$ soil, mixed in each soil type, texture and $\mathrm{pH}$ amended soil and left for 5 days, for establishment of inoculum. Five surface sterilized seeds of chickpea were sown in each pot and data on per cent mortality were recorded 15 days of interval after sowing.

Observations on per cent mortality were started from ten days after inoculation and recorded at five day intervals upto maturity, finally computed as follows.

Per cent incidence

Total infected plant

$=\longrightarrow \times 100$

Total emergence of plant

\section{Results and Discussion}

\section{Effect of soil type on collar rot of chickpea}

Four different soil types are found in Chhattisgarh region that were taken for study. Significantly least mortality per cent (15.27 $\%)$ was recorded in Matasi. However, highest mortality was observed in Kanhar $56.02 \%$. The soil type, Dorsa (31.94 \%) and Bhata $(41.66 \%)$ were statistically at par among themselves.

Soil type also significantly influenced the germination per cent, root length and shoot length in chickpea when inoculated with $S$. rolfsii and data are presented in Table 2 . Highest germination was observed in Kanhar (90 per cent) followed by Matasi and Bhata 86.65 per cent, which were found to be at par with each other. While, the lowest germination per cent was observed in Dorsa that is 83.33 per cent. Maximum root length was observed in Bhata $(23.00 \mathrm{~cm})$ and Khanar $(22.00 \mathrm{~cm})$ followed by Matasi $(17.40 \mathrm{~cm})$ which were at par with each other. Minimum root length was recorded in Dorsa that is $15.80 \mathrm{~cm}$. Maximum shoot length was observed in Khanar (21.00 $\mathrm{cm}$ ) followed by Bhata $(17.80 \mathrm{~cm})$ which were at par with each other. Minimum shoot length was recorded in Dorsa $(16.00 \mathrm{~cm})$ and Matasi $(16.20 \mathrm{~cm})$. Soil type also affects the vigour index of plant. The vigour index is multiplication of germination percentages and seedling length of the final day count. Maximum vigour index was found in Kanhar that is 3870 where as minimum vigour index was recorded in Dorsa (3536.14.) (Table 3).

Nene (1979) reported vertisol soil seems to favour the disease more than alfisol soil. The mortality was high in vertisol which was significantly influenced by soil type when compared to alfisol. Chauhan et al., (2002) reported high wilt incidence in vertisol as it contain high clay content $(64 \%)$. Hussain et 
al., (2006a) studied the effect of soil type (clay, clay loam, sandy loam and sandy) on the incidence of collar rot disease in chickpea caused by $S$. rolfsii and found that the mortality of seedling was higher in clayey soil.

\section{Effect of soil texture on collar rot of chickpea}

Result showed in Table 4 indicated that least mortality per cent $(20.74 \%)$ was recorded in sandy loam texture followed by sandy texture with mortality per cent of $26.67 \%$ which were at par with each other. However, highest mortality was observed in clay texture soil $63.22 \%$, followed by Clay loam $45.83 \%$.

It is clear from the data which showed highest germination in sandy textured soil, (100.0 per cent) followed by Sandy loam $(96.66 \%)$ and Silt loam $(96.66 \%)$ which were significantly superior with other treatments. Loam, Silt clay and Clay loam soil supported chickpea seed to germinate by $93.33,90.00$ and 86.33 per cent, respectively. While, lowest germination per cent was observed in Clay (83.33\%).

Maximum root length was observed in Sandy soil $(22.80 \mathrm{~cm})$ which significantly superior than other treatments. Minimum root length was recorded in Clay soil $(14.20 \mathrm{~cm})$. Maximum shoot length was recorded in Clay soil $(19.80 \mathrm{~cm})$ followed by Loam $(17.80 \mathrm{~cm})$, Silt clay $(17.60 \mathrm{~cm})$ and Silt loam $(17.60 \mathrm{~cm})$ which were at par with each other. Minimum shoot length was observed in Sandy and Clay loam $(15.80 \mathrm{~cm})$. Soil type also affects the vigour index of plant. Maximum vigour index was found in Sandy soil (3860) where as minimum vigour index was in Clay loam (2825.44) (Table 5).

Table.1

\begin{tabular}{|c|c|c|c|c|}
\hline S.No. & Treatment & Soil & Common name & Scientific name \\
\hline $\mathbf{1}$ & T1 & Dorsa & Clayloam & Alfisol \\
\hline $\mathbf{2}$ & T2 & Matasi & Sandyloam & Inceptisol \\
\hline $\mathbf{3}$ & T3 & Kanhar & Clayey & Vertisol \\
\hline $\mathbf{4}$ & T4 & Bhata & Gravely & Entisol \\
\hline
\end{tabular}

Table.2 Effect of soil type on development of collar rot disease in chickpea

\begin{tabular}{|c|c|c|}
\hline S. No. & Soil type & Per cent mortality* \\
\hline $\mathbf{1}$ & Matasi & $15.27(22.75)$ \\
\hline $\mathbf{2}$ & Kanhar & $56.02(48.45)$ \\
\hline $\mathbf{3}$ & Dorsa & $31.94(34.32)$ \\
\hline $\mathbf{4}$ & Bhata & $41.66(40.15)$ \\
\hline \multicolumn{2}{|r|}{} \\
\hline \multicolumn{2}{|r|}{ SEm \pm} & 2.342 \\
\hline & CD $(5 \%)$ & 7.757 \\
\hline
\end{tabular}


Table.3 Effect of soil type on germination and vigour index of chickpea in inoculated soil with S. rolfsii.

\begin{tabular}{|c|c|c|c|c|c|}
\hline S.No. & Soil type & $\begin{array}{c}\text { Germination } \\
(\mathbf{\%})\end{array}$ & Root length $(\mathbf{c m})^{*}$ & $\begin{array}{c}\text { Shoot length } \\
(\mathbf{c m}) *\end{array}$ & $\begin{array}{c}\text { Vigour } \\
\text { index }\end{array}$ \\
\hline $\mathbf{1}$ & Matasi & $86.67(9.3)$ & 17.40 & 16.20 & 2912.11 \\
\hline $\mathbf{2}$ & Kanhar & $90.00(9.5)$ & 22.00 & 21.00 & 3870.00 \\
\hline $\mathbf{3}$ & Dorsa & $83.33(9.1)$ & 15.80 & 16.00 & 2649.89 \\
\hline $\mathbf{4}$ & Bhata & $86.67(9.3)$ & 23.00 & 17.80 & 3536.14 \\
\hline & SEm \pm & 0.264 & 1.673 & 0.721 & \\
\hline & CD $(\mathbf{5 \%})$ & 0.674 & 5.060 & 2.181 & \\
\hline
\end{tabular}

* Average of five replication

Figures in parentheses are square root transformation

Table.4 Effect of different soil texture on development of collar rot disease in chickpea.

\begin{tabular}{|c|c|c|}
\hline S.No. & Soil texture & Per cent mortality* \\
\hline $\mathbf{1}$ & Sandy & $26.67(30.98)$ \\
\hline $\mathbf{2}$ & Sandy loam & $20.74(27.07)$ \\
\hline $\mathbf{3}$ & Loam & $32.22(34.56)$ \\
\hline $\mathbf{4}$ & Clay & $63.22(53.05)$ \\
\hline $\mathbf{5}$ & Clay loam & $45.83(42.57)$ \\
\hline $\mathbf{6}$ & Silt clay & $37.04(37.42)$ \\
\hline $\mathbf{7}$ & Silt loam & $31.11(33.88)$ \\
\hline SEm \pm & & 1.723 \\
\hline CD $(\mathbf{5 \%})$ & & 5.275 \\
\hline *Average of three replication & \\
\hline Figures in parentheses are angular transformation \\
\hline
\end{tabular}

Table.5 Effect of soil texture on germination and vigour index of chickpea in inoculated soil with $S$. rolfsii.

\begin{tabular}{|c|c|c|c|c|c|}
\hline S.No. & Soil texture & Germination (\%) & Root length $\mathbf{( c m )}$ & Shoot length (cm) & Vigour index \\
\hline $\mathbf{1}$ & Sandy & $100.0(10.0)$ & 22.80 & 15.80 & 3860.00 \\
\hline $\mathbf{2}$ & Sandy loam & $96.66(9.8)$ & 18.80 & 16.00 & 3364.12 \\
\hline $\mathbf{3}$ & Loam & $93.33(9.7)$ & 18.40 & 17.80 & 3378.55 \\
\hline $\mathbf{4}$ & Clay & $83.33(9.1)$ & 14.20 & 19.80 & 2833.22 \\
\hline $\mathbf{5}$ & Clay loam & $86.66(9.3)$ & 16.80 & 15.80 & 2825.44 \\
\hline $\mathbf{6}$ & Silt clay & $90.00(9.5)$ & 19.00 & 17.60 & 3294.00 \\
\hline $\mathbf{7}$ & Silt loam & $96.66(9.8)$ & 19.40 & 17.60 & 3576.79 \\
\hline SEm \pm & & 0.147 & 0.475 & 0.374 & \\
\hline $\begin{array}{l}\text { CD } \\
(\mathbf{5 \%})\end{array}$ & 0.451 & 1.383 & 1.090 & \\
\hline *Average of three replication & & & \\
\hline **Average of five replication \\
\hline Figures in parentheses are square root transformation
\end{tabular}


Table.6 Effect of different $\mathrm{pH}$ on development collar rot disease in chickpea

\begin{tabular}{|c|c|c|}
\hline S. No. & pH & Per cent mortality \\
\hline $\mathbf{1}$ & 5 & $47.62(43.61)$ \\
\hline $\mathbf{2}$ & 5.5 & $53.96(47.33)$ \\
\hline $\mathbf{3}$ & 6 & $80.75(64.27)$ \\
\hline $\mathbf{4}$ & 6.5 & $63.69(52.99)$ \\
\hline $\mathbf{5}$ & 7 & $43.98(41.50)$ \\
\hline $\mathbf{6}$ & 7.5 & $38.42(38.26)$ \\
\hline $\mathbf{7}$ & 8 & $24.07(29.36)$ \\
\hline $\mathbf{8}$ & 8.5 & $19.90(26.26)$ \\
\hline SEm \pm & \multicolumn{2}{|l}{} \\
\hline CD $\mathbf{5 \%}$ ) & \multicolumn{2}{|l}{} \\
\hline *Average of three replication & 11.24 \\
\hline Figures in parentheses are angular transformation \\
\hline
\end{tabular}

Table.7 Effect of different $\mathrm{pH}$ on germination and vigour index of chickpea in inoculated soil with $S$. rolfsii

\begin{tabular}{|c|c|c|c|c|c|}
\hline S. No. & pH & $\begin{array}{c}\text { Germination } \\
(\mathbf{\%})\end{array}$ & $\begin{array}{c}\text { Root length } \\
(\mathbf{c m})\end{array}$ & $\begin{array}{c}\text { Shoot length } \\
(\mathbf{c m})\end{array}$ & $\begin{array}{c}\text { Vigour } \\
\text { index }\end{array}$ \\
\hline $\mathbf{1}$ & 5 & $63.33(8.0)$ & 13.60 & 16.60 & 1912.57 \\
\hline $\mathbf{2}$ & 5.5 & $66.66(8.2)$ & 14.00 & 17.80 & 21119.79 \\
\hline $\mathbf{3}$ & 6 & $70.00(8.4)$ & 12.60 & 19.80 & 2268.00 \\
\hline $\mathbf{4}$ & 6.5 & $73.33(8.6)$ & 14.40 & 20.40 & 2551.88 \\
\hline $\mathbf{5}$ & 7 & $90.00(9.5)$ & 18.60 & 21.80 & 3636.00 \\
\hline $\mathbf{6}$ & 7.5 & $86.66(9.3)$ & 19.20 & 20.60 & 3449.07 \\
\hline $\mathbf{7}$ & 8 & $83.33(9.1)$ & 19.60 & 20.80 & 3366.53 \\
\hline $\mathbf{8}$ & 8.5 & $83.33(9.1)$ & 19.20 & 21.00 & 3349.87 \\
\hline SEm \pm & & 0.231 & 0.650 & 0.574 & \\
\hline $\begin{array}{c}\text { CD } \\
\text { (5\%) }\end{array}$ & 0.699 & 1.881 & 1.662 & \\
\hline *Average of three replication & & & \\
\hline **Average of five replication & & & \\
\hline Figures in parentheses are square root transformation & & \\
\hline
\end{tabular}

In agreement to above findings, Hussain et al., (2006) found that in clayey soil, seedling death was $94 \%$ whereas in clay loam, sandy loamy and sandy soils, it was 82,78 and $60 \%$, respectively. Seedling death in sandy soil was significantly less than that noted in all other types of soil. Mahato et al., (2017) reported that incidence of collar rot varied with different soil textures. Maximum incidence
$(100 \%)$ was observed in sandy clay loam followed by sandy clay (88.33\%), silt clay loam (56.67\%), Clay loam (43.33\%) and minimum disease incidence recorded in silt loam (36.67\%). Results reveled that Sandy clay loam soil was highly favorable for collar rot disease. Banyal et al., (2008) also reported that lighter soils were more favourable to the collar rot disease of tomato caused by 
Sclerotium rolfsii than the heavy textured soils.

Effect of different $\mathrm{pH}$ on collar rot of chickpea

Significantly least mortality per cent (19.90\%) was recorded at $\mathrm{pH} 8.5$ followed by $\mathrm{pH} 8$ (24.07\%), pH 7.5 (38.42\%), pH 7 (43.98\%), $\mathrm{pH} 5(47.62 \%)$ and $\mathrm{pH}(53.96 \%)$ which were next in order. However, significantly highest mortality was observed at $\mathrm{pH} 6.0$ that is, 80.75 $\%$ followed by $\mathrm{pH} 6.5$ (63.69). All the treatment differ significantly in terms of mortality per cent with each other, except $\mathrm{pH}$ 5, pH 5.5, pH 7 and pH 7.5 (Table 6).

Highest germination was observed in $\mathrm{pH} 7.0$ that is 90.00 per cent, followed by $\mathrm{pH} 7.5$ with 86.66 per cent which were at par with each other. Whereas lowest germination was observed in $\mathrm{pH} 5$ that 63.33 per cent followed by $\mathrm{pH} 5.5$ (66.66 per cent) which were at par with each other. Maximum root length was observed in $\mathrm{pH} 8.0(19.60 \mathrm{~cm})$ followed by $\mathrm{pH}$ 7.5, $\mathrm{pH} 8.5(19.20 \mathrm{~cm})$ and $\mathrm{pH} 7(18.60 \mathrm{~cm})$ which were at par, but significantly better than other treatments. Minimum root length was recorded in $\mathrm{pH} 5$ that is 13.60 and $\mathrm{pH} 5.5$ $(14.00 \mathrm{~cm})$ (Table 7).

Maximum shoot length was observed in $\mathrm{pH}$ $7.0(21.80 \mathrm{~cm})$ followed by $\mathrm{pH} 8.5 .(21 \mathrm{~cm})$, $\mathrm{pH} 8.0(20.80 \mathrm{~cm}), \mathrm{pH} 7.5(20.40 \mathrm{~cm})$ and $\mathrm{pH}$ $6.5(20.40 \mathrm{~cm})$ which were at par with each other.

Whereas, minimum shoot length was recorded in $\mathrm{pH} 5.0(16.60 \mathrm{~cm})$. Highest vigour index was found in $\mathrm{pH} 7$ that is 3636.00 whereas least was in $\mathrm{pH} 5$ that is 1912.57. Similar findings were given by Mahato et al., (2017) who reported that highest incidence $(100 \%)$ was recorded at 6.5 and $7.0 \mathrm{pH}$ level and lowest incidence $(51.67 \%$ ) was recorded at 8.0 $\mathrm{pH}$ level.
Prasad et al., (1986) found the $\mathrm{pH}$ range of 5.0 to 7.0 as best for sclerotial formation at different temperatures in vitro. Wide range of $\mathrm{pH}$ with optimum near 6.0 for the growth of various isolates of Sclerotium rolfsii have been reported by Aycock (1966), Narasimhan (1969) and Sharma and Kaushal (1979). Banyal et al., (2008) reported that maximum death of tomato caused by Sclerotium rolfsii at 6.5-7.5 $\mathrm{pH}$ level in green house experiments.

\section{References}

Aycock, R. 1966. Stem rot and other disease caused by Sclerotium rolfsii. Technical Bull. North Carolina Agricultural Experimental Station. pp 174-202.

Banyal, D. K., Mankotia, V. and Sugha, S.K. 2008. Soil characteristics and their relation to the development of tomato collar rot caused by Sclerotium rolfsii. Indian Phytopath., 61 (1): 103-107

Chauhan, V.B., Singh, V.B. and Singh, A.K. 2002. Status of phytophthora blight of pigeon pea in eastern Uttar Pradesh. Ann. Pl. Protec. Sci., 10: 402-404.

Hussain, A., Iqbal, S.M., Ayub, N. and Zahid, M.A. 2006. Factors affecting development of collar rot disease in chickpea. Pakistan Journal of Botany. 38(1):211-216.

Kotastthane, S.R., Agarwal, P.S., Joshi K.K. and Sing. L.1976. Studies on wilt complex in Bengal gram (Cicer arietinum L.). JNKVV Res. J., 10: 257258.

Kulkarni, V. R. 2007. Epidemiology and integrated management of Potato wilt caused by Sclerotium rolfsii Sacc. Ph.D. Thesis, University of Agricultural Sciences, Dharwad.

Mahato, A. and Biswas, M. K. 2017. Cultural, Morphological and Pathogenic Variability of Different Isolates of Sclerotium rolfsii Obtained from Rice- 
Tomato-Rice Cropping System of Undulating Red and Lateritic Zone of West Bengal, India Int.J.Curr.Microbiol.App.Sci., $\quad 6(3)$ : 1843-1851.

Narasimhan, R. 1969. Physiological studies on the genus sclerotium. I Effect of initial $\mathrm{H}$. Ion concentration on the growth of Sclerotium rolfsii and sclerotium oryzae in different inorganic nitrogen media. Indian Phytopathology. 22:115123.

Nene, Y.L., Sheila V.K. and Sharma S.B. 1984. A world list of chickpea (Cicer arietinum L.) and pigeonpea (Cajnus cajan (L.) Millsp.) pathogens. ICRISAT Pulses Pathology Progress Report, 32, pp.19.
Prasad, B.K., Thakur, S., Sinha, P and Prasad A. 1986. Influence of nutritional factor, $\mathrm{pH}$ and temperature on growth of Sclerotium rolfsii Sacc. isolated from tomato fruits. Indian Journal of Mycology and Plant Pathology. 16(2): 209-212.

Punja, Z.K. 1988. Sclerotium (Athelia) rolfsii, a pathogen of many plant species. In: Sidhu GS, ed. Genetics of plant pathogenic fungi. Vol. 6. London: Academic Press. pp. 523-534.

Sharma, S.L., Kaushal, B.R. 1979. Cultural and physiological studies with sunflower isolate of Sclerotium rolfsii. Indian journal of the Mycology and Plant Pathology. 9:105-107.

\section{How to cite this article:}

Shirsole, S.S., N. Khare, N. Lakpale and Kotasthane, A.S. 2019. Study of Soil Factors Affecting Development of Collar Rot Disease in Chickpea. Int.J.Curr.Microbiol.App.Sci. 8(11): 2323-2330. doi: https://doi.org/10.20546/ijcmas.2019.811.269 